\title{
MODERN PEDAGOGICAL MECHANISMS FOR THE FORMATION OF ETHNECOLOGICAL CULTURE IN THE HIGHER EDUCATION SYSTEM
}

\author{
Nigorakhon Pulatova \\ lecturer Fergana State University
}

\section{ABSTRACT}

The article discusses the importance of ethnecological research in the formation of ethnecological culture of students in their pedagogical mechanisms.

KEYWORDS:- Ethnecological culture, ecological problems, environmental, education, ethnecological verification, natural resources, educational process.

\section{INTRODUCTION}

Through the above ideas and considerations an attempt is made to reveal the natural and sociopedagogical essence of ethno-ecological culture patterns that maintain ecological balance. Emphasis is placed on the flexibility of ethnic groups in the life support system. The natural, material, social and pyschological resilience of ethnic groups to the environment is seen as the basis for maintaining ethno-demographic, ethnocultural balanve and sustaniable development in society .

To control the ecological stability of the region . By the new millennium, the system of ethnoecological control will play an important role in the development of modern civilization, not only in improving the natural living conditions of man and the rational use of medical resources, but also in determining the future of human civilization . Therefore, yhe current problems of the ethno-ecological control system are beimg diligantly studied by both supervisors and practitioners.

\section{Methods}

The system of ethno-ecological control, aimed at controlling the conscious relationship of ethnic communities with nature in society, is an activity aimed at drawing the right conclusions from the global environmental problems that the people are facing, identifying the causes of ethnos in ecological crisis.

Preserving the self-healimg potentional of the biosphere. For environmental activity to become a cultural phenomenon, it must serve as a means of satisfying human needs. However, environmental activity is not a spontaneous phenomenon, but it requires a unversal institutional stucture. That is, anti-human 
CURRENT RESEARCH JOURNAL OF PEDAGOGICS 2(5): 108-113, May

2021 DOI: https://doi.org/10.37547/pedagogics-crjp-02-05-19

ISSN 2767-3278

(C)2021 Master Journals

Crossref doi 8 Google

Accepted 25th May, 2021 \& Published 31 th May, 2021

activities that harm human health, life, peace , work, leisure and development are becoming direct and indirect objects of the institutional system of environmental control.

Therefore, the creation of control mechanisims in the ethno-ecological culture, which is the object of this researcg, the formation of ethnoecological control activities in the life of each ethnic community, forming in them a conscious attitude to nature, responsibility.

At certain stages of human development, the savage use of natural resources, fierce competition, and not only the political and economic opperssion of colonialism, but also the " wild economy" based on environmental pollution, put environmental control in the background . it is the negative consequences of this wild economy thet necessitate the formation of an ethno-ecological culture today.

After the transitions to the post-industrial stage of the developed societies in the West, ecological and cultural activities based on the conservation of natural resources, ecologically clean tecgnology, scientific achievements were formed. In this situation, the system of ethno-ecological control, as anecessary institution of the economy, has been developing since primitve times. It is true that in the past the needs for development of the ecological activity of the ethnos in the traditional primitive management were narrow, local in nature, but in course of historical development, they have grown.

In our opinion, the stuructre of the socio-political system of the ethno-ecological control

- $\quad$ needs of ethno-ecological control system

- $\quad$ socio-political subjects of ethnoecological control

- activity of ecological control of ethnos and ethnic community factor

- $\quad$ public interest in ethno-ecological control
- formation of ethno-ecological culture

- $\quad$ legal bases of ethno-ecological control and other similar components.

Today, environmental pollution and the growing desire to dominate nature pose a global threat to the lives of peoples due to climate change. In such a situation, it is more important for each society to form its own ethno-ecological culture and ethno-ecological resposibility than to place the responsibility on others . Indeed, the system of ethno-ecological control can be divided according to the conditions of its existence, the method of means .

In addition, in ethno-ecological control, the connection of institute systems with the production process: the organization of production realations, tools, labor, machinary, technology, transport, energyand other material values on the basis of envirnomental requirements, management functions, interaction, regulates a number of its spritual factors :

- ethno-ecological conciosness, thinking, interests, views, theories, issues, beliefs, ideas, feelings and norms, covers and elemnets.

In today's context of global change, there is a need to provide students with effective methods and tools to provide information about the real situation. In this situation, it is necessary to develop national startegy for ethno-ecological risks, problems and their elimination, to create mechanisms for the rational use of the ethnoecological situation. To do this, first of all, it is necessary to form ethno-ecological consciousness in society.

Ethnological consciousness plays a special role in the sturcture of the funcitional element of the ethno-ecological control. In general " the phenemenon of consciousness is a function of society". For ethno-ecological consciousness is a subjective denial of objective events and 
CURRENT RESEARCH JOURNAL OF PEDAGOGICS 2(5): 108-113, May

2021 DOI: https://doi.org/10.37547/pedagogics-crjp-02-05-19

ISSN 2767-3278

(C)2021 Master Journals

\section{Crossref do) 81 Google}

Accepted 25th May, 2021 \& Published 31 th May, 2021

processesn by the ethnos and has a stuctural stuructre. They are :

- $\quad$ caution to ethno-ecological control

- ethno-ecological emotion

- practice of ethno-ecological control

- forecast of ethno-ecological control

In general, ethno-ecological culture is a necessity of society. Because it realizes the knowladge and skills, abilities, talents, goals and interests necessary for the ecological activity of the ethnic community and their dreams and iedeas come true.

\section{Results AND DISCUSSIONS}

It is known that the satisfaction of ethnoecological needs depends on the protection of nature in the ethnic community, spiritual satisfaction, aesthetic enjoyment creates an emotional state, unfulfilled needs, discriminated interests do not create ecologically favorable conditions in the ehtnic community, it evokes negative emotions such as dissatisfaction, passivity, suffering, depressionand depression from the existing political system. Also, even if the ethno-ecological situation is conductive to certain activities in extereme conditions, the state of "environmentaltension" can be maintained aven if the goal is achieved. Even if the ecological situation is good and the goals are achieved, people may not feel satisfied with their work.

For example, there are many expamles of weapons of mass destuction enterprises being based on environmentally friendly technologies, the formation of a high level of environmental control, and the negative impact on the "spiritual ecology" of those who work in these enterprises.

In short, the most effective way to develop environmental education in society, to form an ethno-ecological culture, is to improve the science of higer education on an innovative basis, to change the approach, and thus to develop students' skills of rational use of nature. In today`s global environmental crisis, the formation of ethno-ecological culture in each ethnic communityand thus the solution of the problem of environmental sustainability through the creation of special educational technologies in the education system, is a priority .

The priorities in the formation of ethnoecological culture in the framework of the concept of development of environmental education in the Republic of Uzbekistan are as follows:

There is a need to assess the current state of the educational process, to develop tasks for the development of environmental education and to form an ethno-ecological worldview through the improvement of educational programs based on existing environmental problems and their solutions.

to strengthen the responsibility of students of higher education institutions for the conservation and rational use of non-renewable resources of Mother Nature by developing the ecological worldview, objectifying the approach to the formation of a rational attitude to nature and drawing students' attention to global environmental problems;

formation of ecological stability in the system of higher education through the development and introduction of effective forms and methods of ecological education, as well as the use of spatial features in economic development, economic management, rational use of national ecoecological features; also targeted.

The system of higher education also provides for the creation of ethno-ecological education, which is an integral part of environmental education, and thus the quality of ethno-ecological culture, the effectiveness of the training system and the 
CURRENT RESEARCH JOURNAL OF PEDAGOGICS 2(5): 108-113, May

2021 DOI: https://doi.org/10.37547/pedagogics-crjp-02-05-19

ISSN 2767-3278

(C)2021 Master Journals

Crossref doi 81 Google

Accepted 25th May, 2021 \& Published 31 th May, 2021

guarantees and priorities of sustainable

development;

Tasks have been developed to develop mutually beneficial cooperation between the competent state bodies in the field of ecology and environmental protection and education, thereby creating an ethno-ecological outlook in society, principles of ethno-ecological activity in management, mechanisms for evaluating the effectiveness of ethno-ecological activity.

If the pedagogical process aimed at the development of ethno-ecological culture in students in higher education is organized on the basis of interdisciplinary cooperation and the relationship of "ethno-spatial-economic" system is placed in the form of "geotrions", the main burden falls on will be displayed. It is obvious that only the economic indicators of the ethnos that meet the requirements of the space are preserved as a "skill-skill-tradition". With the development of "ethno-spatial-economic" relations, the amount of the natural biosphere in any region will decrease, and will be replaced by indicators of the Technosphere. Therefore, it is necessary to pay special attention to environmental education in the education system and use it wisely, taking into account national characteristics, without compromising environmental diversity.

The formation of ethno-ecological culture in university students should be carried out after the development of ethno-ecological research and the formation of the theoretical basis. Because the resources, theoretical materials, literature and textbooks from the subjects taught in higher education institutions today remain ineffective due to the problem. The issue of zoning the study of ethno-ecological culture in historical-pedagogical and geographical knowledge is considered first, as observed in the historical approach. It focuses on the concepts of "ethnic territory", "ethnic space", "ethnic boundary", "ethnic core" [3; 152]. However, in small areas where different ethnic groups, such as Uzbekistan, are mixed, it is almost impossible to use the above units. Therefore, the concept of 'ethnic core' is used to study small areas from the above units.

Historical cultural (ethnographic) regions are formed in a certain cultural community as a result of a single historical destiny, as well as long-term interactions of peoples living in similar places. In such regions, ethnic systems with local peculiarities, common material and spiritual culture emerge in time and region. According to this phrase, introduced to science by linguist NI Tolstoy, the ethnocultural landscape is a traditional ethnic landscape. The main regional-local criteria for its separation are the preservation of traditional forms of nature use, the existence of traditional construction and architecture, the preservation of language and folklore traditions, adherence to traditional beliefs, the preservation of the image and name of the place.

At the same time, the principle that ethnic groups recognize which subethnic cultural stratum they belong to, and that the center changes depending on distance or proximity, is taken into account.

In the formation of ethno-ecological culture in Uzbekistan, raising the ethno-ecological outlook and thinking in the education system, determined by the need.

However, a systematic analysis of the process of environmental education shows that there are still serious problems and shortcomings in the organization of environmental education, which hinder the full implementation of reforms in this area"[2].

Therefore, it is necessary to strengthen, develop and improve environmental education in the higher education system on the basis of new approaches, and thus to form a national 
CURRENT RESEARCH JOURNAL OF PEDAGOGICS 2(5): 108-113, May

2021 DOI: https://doi.org/10.37547/pedagogics-crjp-02-05-19

ISSN 2767-3278

(C)2021 Master Journals

Crossref doi 8 Google

Accepted 25th May, 2021 \& Published 31 th May, 2021

environmental culture and use it for social development, building a prosperous life. In the pedagogical study of ethnoecological culture, we have also developed a specific model in the following form, based on the above methodological basis.

In higher education, students need to pay attention to the ecologically important aspects of each component in the formation of ethnoecological culture, the study of its components. In the formation of ethno-ecological culture in students, natural space conditions and resources are absorbed through the study of the "environmental" nature of ethno-ecological culture, its introduction into the educational process. Therefore, the stabilization of the ethnoecological situation in Uzbekistan requires the rational use of species with the same ecological conditions. On this basis, the economic (agricultural) and ethnic (skills, qualifications and traditions) indicators that cause environmental problems within the separated ethnocultural regions and ethno-ecological regions are analyzed.

This requires students to study the cultural characteristics of ethnic communities, the results of their conscious relationship with nature, to explain the pedagogical mechanisms of effective use of the experience of ethnic communities in the formation of environmental sustainability.

In the teaching of ethno-ecological culture in the higher education system, there is a need to pay attention to the culture of land and water use and their ecological basis, rather than the system of "traditional farming", which is another component of ethno-ecological culture.

It is necessary to study the territorial aspects of land and water use in the ethno-ecological direction from the economic indicators that cause environmental problems in Uzbekistan today.
Partial preservation of traditional forms of economy (agriculture, animal husbandry, horticulture) in the region allows to preserve other components of ethno-ecological culture, and conversely, the sudden destruction of traditional economy can lead to the destruction of the entire ethno-ecological culture and tragic ethno-ecological consequences

One of the important tasks in the formation of ethno-ecological culture among university students is the study of the territorial location of settlements and the factors influencing it. In the component of ethno-ecological culture called "settlement" the territorial location of settlements and the geographical factors influencing it are analyzed in detail. Socioecological factors that lead to the territorial location of settlements, the name of the settlement and its etymology, its reflection of natural and social conditions, the ethnic composition of the population are considered [5; 48]. This is explained by the location of the population and its potential, the ecological situation in the region, the study of the values formed through the relationship of the population with nature, their knowledge and their use in the formation of environmental sustainability

Therefore, the specific features of settlements under the influence of environmental factors (their shrines, shrines, "ecological quiet areas") are analyzed cartographically.

In the pedagogical process, it is expedient to provide students with an analysis of the ethnoecological situation and socio-family relations in cooperation with the social sciences and ecology. In the section entitled "Ethnic community" of ethno-ecological culture, indicators such as ethnological, socio-family, confessional aspects, type of ethnic groups, demographic indicators, in which sector of the economy are most employed are also presented. In this regard, according to 
CURRENT RESEARCH JOURNAL OF PEDAGOGICS 2(5): 108-113, May

2021 DOI: https://doi.org/10.37547/pedagogics-crjp-02-05-19

ISSN 2767-3278

(C)2021 Master Journals

\section{Crossref do) 81 Google}

Accepted 25 ${ }^{\text {th }}$ May, 2021 \& Published 31 ${ }^{\text {th }}$ May, 2021

the Russian scholar VN Kalutskov, in recent years, special attention has been paid to the attitude of the ethnic community to the symbol of "place", the ways of expressing it in geographical songs[5; 244].

Therefore, the living space of an ethnic community and its natural resources and the traditions and customs formed on this basis are also ethno-ecological culture.

Today, the higher education system not only forms modern knowledge and skills for students, but also inculcates in them moral and cultural values. Because along with potential personnel, it is very important for the society to cultivate responsible, selfless and honest personnel. Therefore, educating young people to be responsible for nature is also important

\section{Conclusion}

Therefore, in the formation of ethno-ecological culture in higher education, students are taught important information about the territorial location of sacred sites and shrines, their ecological function, ecological recommendations, prohibitions, instructions of religion in the direction of religious beliefs of ethnic groups.

It should be noted that the linguistic and spiritual components of ethno-ecological culture perform an additional function in addition to the above

These components also serve to describe, preserve, and transmit other components of ethnoecological culture in space and time $[5 ; 69]$. This function of these components, in our opinion, coincides with the development of proposals and recommendations for sustainable development in the region, using the process of environmental education, as well as ethnoecological culture. Such a methodological approach provides an opportunity to distinguish from each component of ethno-ecological culture the aspects necessary for our research, ensuring sustainable development, maintaining ecological balance.

\section{REFERENCES}

1. Kochurov B.I. Ecodiagnostics and balanced development. Textbook-M .: INFRA-M. 2016,262 p.

2. Development of ecological education in the Republic of Uzbekistan, developed on the basis of the resolution of the Cabinet of Ministers of the Republic of Uzbekistan from May 27, 2019 of No. 434

3. Vedenin Y.A. Formation of a new cultural and ecological approach to the preservation of heritage // Ecology of culture: Almanac of the Institute of Heritage "Territory." -M: Heritage Institute, 2000, p. 152.

4. Gumelev L.N. Ethnogenesis and the biosphere of the Earth.L .: Gidrometeoizdat, 1990.-p. 528

5. Kalutskov V.N. Landscape in cult geography.M.: New chronograph, 2008-p. 48,69,244.

6. Krapivenskiy S.E. Social Philasophia.-M.: Humanities Publishing Center. "Vlados", 1998, p. 220.221.

7. Gaybullaeva M. F. The Role Of Biomass In Saving Natural Resources //The American Journal of Horticulture and Floriculture Research. - 2021. - T. 3. - №. 02. - C. 1-6. 